Société d'histoire de la révolution de 1848 et des

révolutions du XIXe siècle

$19 \mid 1999$

Aspects de la production culturelle au XIXe siècle

\title{
Les journaux du printemps 1848 : une révolution médiatique en trompe-l'œil
}

\section{Anne-Claude Ambroise-Rendu}

\section{OpenEdition}

\section{Journals}

Édition électronique

URL : http://journals.openedition.org/rh19/154

DOI : $10.4000 /$ rh19.154

ISSN : $1777-5329$

\section{Éditeur}

La Société de 1848

\section{Édition imprimée}

Date de publication : 1 décembre 1999

Pagination : $35-64$

ISSN : 1265-1354

\section{Référence électronique}

Anne-Claude Ambroise-Rendu, «Les journaux du printemps 1848 : une révolution médiatique en

trompe-l'œil », Revue d'histoire du XIXe siècle [En ligne], 19 | 1999, mis en ligne le 26 août 2008, consulté le 22 avril 2019. URL : http://journals.openedition.org/rh19/154 ; DOI : 10.4000/rh19.154

Ce document a été généré automatiquement le 22 avril 2019.

Tous droits réservés 


\title{
Les journaux du printemps 1848 : une révolution médiatique en trompe-l'œil
}

\author{
Anne-Claude Ambroise-Rendu
}

\section{RÉSUMÉS}

La liberté offerte à la presse par la révolution de 1848 sonne le coup d'envoi non pas tout à fait d'une nouvelle période de la production et de la diffusion médiatique, mais au moins des représentations que professionnels, amateurs et usagers de la presse se font de son rôle, de ses possibilités et de son influence. En quelques semaines, plus de 300 titres se créent à Paris, presque autant en province. La liberté acquise permet à tous ceux qui en ont les moyens d'imprimer leur feuille: les numéros un, parfois deux et trois, qui paraissent en février, et jusqu'en juin 1848, offrent de ce point de vue un avant-goût remarquable de la manière dont la presse participe de l'intensification des échanges et de la circulation culturelle pour, en usant de sa périodicité ou tout au moins du potentiel qui est le sien en ce domaine, s'inscrire dans le registre de la culture de masse. L'étude des formats, de la typographie, de la pagination, mais aussi des titres et du système de connotation politique auxquels ils renvoient, doit permettre de mettre en relief la façon dont un journal orchestre ses appels auprès d'un public nouveau qui est donc doublement à conquérir et à fidéliser. Que la discontinuité, l'exceptionnel l'emportent ici sur la durée dit assez que l'énergie impulsée par une révolution politique contamine presque directement les formes de la vie culturelle. Mais l'échec que connut la presse de 1848 n'est pas seulement politique. Il tient aussi aux déficiences mêmes de l'organisation commerciale, déficiences auxquelles la presse de l'Empire et plus encore celle de la IIIe République sauront remédier. La matérialité de l'efflorescence médiatique de l'hiver et du printemps 1848 permet 
donc de pointer assez précisément ce qui est d'ores et déjà en jeu dans l'essor de la presse et dans la manière dont il s'inscrit dans l'évolution culturelle du XIXe siècle.

The freedom granted to the press by the 1848 revolution is the "kick off" not so much of a new period of production and circualtion of the media, but rather of the representations that press professionals, keen amateurs and press users have of its role, its possibilities and its influence. Within a few weeks, nearly 300 newspapers are created in Paris and almost as many in the province. The newly acquired liberty allows all those who can afford it to print their own paper. The first and sometimes the second and third newspaper issues that appear in February and up to June 1848 actually give a remarkable foretaste of the manner in which by use of its periodicity or at least of its own very potential in this field, the press partakes of the intensification of cultural exchanges and the spreading of culture to fit in with the range of mass culture. The study of formats, typography, pagination as well as that of titles and the system of political connotation they refer to, shall permit to emphasize the manner in which a newspaper orchestrates its advances to a new reading public which is both to conquer and establish. That discontinuity and the exceptional should prevail over duration shows well enough that the energy boosted by a political revolution will almost directly affect the forms of cultural life. However, the failure that the press met with in 1848 is not solely political. It is also due to the very deficiences of commercial organization which the press of the Second Empire and even more so the press of the Third Republic will be able to remedy. The materiality of the efflorescence of the media in winter and spring 1848 allows to point out fairly accurately what is already at stake in the development of the press and the manner it fits in with the cultural evolution of the XIXth century.

INDEX

Mots-clés : Presse, Histoire culturelle 